\title{
Computer-Aided Identification, Synthesis, and Biological Evaluation of Novel inhibitors for Botulinum Neurotoxin Serotype A
}

\author{
Yu-Han Gary Teng ${ }^{\mathrm{a}}$, William T. Berger ${ }^{\mathrm{b}}$, Natasha M. Nesbitt ${ }^{\mathrm{a}}$, Kunal Kumar ${ }^{\mathrm{a}}$, Trent E. Balius ${ }^{\mathrm{d}}$, Robert C. \\ Rizzo $^{\mathrm{a}, \mathrm{d}}$, Peter J. Tonge ${ }^{\mathrm{a}, \mathrm{b}}$, Iwao Ojima ${ }^{\mathrm{a}, \mathrm{b} *}$ and Subramanyam Swaminathan ${ }^{\mathrm{a}, \mathrm{c}}$ \\ ${ }^{a}$ Institute of Chemical Biology and Drug Discovery, Stony Brook University, Stony Brook, NY 11794, United States \\ ${ }^{b}$ Department of Chemistry, Stony Brook University, Stony Brook, NY 11794, United States \\ ${ }^{c}$ Biological, Environmental \& Climate Sciences Department, Brookhaven National Laboratory, P.O. Box 5000, Upton, New York 11973-5000, United States \\ ${ }^{d}$ Department of Applied Mathematics \& Statistics, Stony Brook University, Stony Brook, NY 11794, United States
}

\section{ARTICLE INFO}

\section{Article history:}

Received

Revised

Accepted

Available online

\section{Keywords:}

Botulinum neurotoxin

BoNT/A-LC inhibitor

SNAPtide

SNAP-25

HTP in silico screening

\section{ABSTRACT}

Botulinum neurotoxins (BoNTs) are among the most potent biological toxin known to humans, and are classified as Category A bioterrorism agents by the Centers for Disease Control and prevention (CDC). There are seven known BoNT serotypes (A-G) which have been thus far identified in literature. BoNTs have been shown to block neurotransmitter release by cleaving proteins of the soluble NSF attachment protein receptor (SNARE) complex. Disruption of the SNARE complex precludes motor neuron failure which ultimately results in flaccid paralysis in humans and animals. Currently, there are no effective therapeutic treatments against the neurotoxin light chain (LC) after translocation into the cytosols of motor neurons. In this work, high-throughput in silico screening was employed to screen a library of commercially available compounds from ZINC database against BoNT/A-LC. Among the hit compounds from the insilico screening, two lead compounds were identified and found to have potent inhibitory activity against BoNT/A-LC in vitro, as well as in Neuro-2a cells. A few analogues of the lead compounds were synthesized and their potency examined. One of these analogues showed an enhanced activity than the lead compounds. 


\section{Introduction}

Botulinum neurotoxins (BoNTs) produced by anaerobic bacteria Clostridium botulinum are the most potent biological toxin known, and they are classified as Category A bioterrorism agents by the Centers for Disease Control and Prevention (CDC). ${ }^{1-4}$ Although the toxin has found its way to the applications of medical treatments and cosmetic improvements, 5,6 the potential use as a bio-weapon in terrorism still largely remains. The BoNT/A serotype has lethal dose of $1.3 \mathrm{ng} / \mathrm{kg}$, and it is estimated that one gram of the aerosolized toxin can kill as much as 1 million people. ${ }^{1,2}$ Therefore it is a necessity to develop the therapeutic countermeasures against the BoNTs.

All serotypes function by the same mechanism, but target different SNARE proteins (SNAP-25, syntaxin or synaptobrevin) and sequences. ${ }^{6-8}$ Through experimental evidence BoNTs are known to vary in structure substantially among the serotypes, and as such, substrates also vary substantially. ${ }^{9}$ Currently there are no known inhibitors providing broad-spectrum inhibition against BoNTs. Thus, most of the literature has focused on the development of inhibitors against BoNT/A; the most potent toxin and the major cause of human botulism.

There are seven serologically distinct toxin types designated A to $\mathrm{G}$. Type $\mathrm{A}$ is the most potent toxin, followed by types B and $\mathrm{F}$ toxin. Types A, B and E are commonly associated with systemic botulism in humans. ${ }^{10}$ The toxin is a twochain polypeptide with a $100 \mathrm{kDa}$ heavy chain joined by a disulfide bond to a $50 \mathrm{kDa}$ light chain. This light chain is a zinc metalloprotease that cleaves the SNARE protein complex at a neuromuscular junction. As a result, the release of acetylcholine at the neuromuscular junction is ceased and leads to flaccid paralysis and eventual respiratory failure.

\section{Results and Discussion}

\subsection{High-throughput virtual screening}

The initial attempts at designing catalytic inhibitors of BoNT/A was focus on peptidomimetics. The tetrapeptide RRGC was found to have strong inhibitory activity $\left(\mathrm{K}_{\mathrm{i}}\right.$ of 157 nM) against BoNT/A-LC. ${ }^{11}$ The X-ray co-crystal structure of RRGC in BoNT/A-LC (PDB ID: 3C88) provides us the key feature of the interaction of the inhibitor with the protein. ${ }^{11}$

In the attempt to identify new BoNT/A-LC inhibitors, a large-scale virtual screening of over one million commercially available compounds was performed and resulted in the purchase of compounds for subsequent experimental evaluations. Traditionally many screening programs such as DOCK $^{12-14}$ employ a simple two-term scoring function consisting of intermolecular van der Waals and electrostatic terms to rank-order compatibility of ligands with a target. A relative new scoring function developed by the Rizzo laboratory, termed "molecular footprint similarity (FPS)" score, utilizes the standard scoring function as a decomposition of the energy by per-residue contributions. ${ }^{15}$

High-throughput virtual screen utilizing FPS score was conducted on BoNT/A-LC (PDB: 3C88, $1.60 \AA$ resolution) ${ }^{11}$ using tetrapeptide RRGC $\left[\mathrm{K}_{\mathrm{i}}=157 \mathrm{nM}\right]$ as the reference ligand. The rational was to find small molecule inhibitors that possessed similar activity to the RRGC tetrapeptide while providing more robust scaffolds for chemical modification. As the result of the virtual screening, 99 compounds were ultimately selected, purchased, and assayed in vitro.

\subsection{High-throughput biological screening}

A high-throughput SNAPtide assay was used to screen the 99 selected compounds from the virtual screening. The assay carried out with protein concentration of $100 \mathrm{nM}$, the addition of $0.15 \mathrm{mM} \mathrm{ZnCl}{ }_{2}$ and $1.25 \mathrm{mM}$ DTT. The quantity of SNAPtide was $5 \mu \mathrm{M}$, and the results are shown in Table 1 .

Based on the $\mathrm{IC}_{50}$ values thus obtained from the assay, compounds with FPS $\mathrm{VDW}_{\mathrm{ES}}$ scores of greater than 0.90 appear to have better activity, and the structures and the footprint overlay of the best 2 hit compounds with RRGC are shown in Figure 1.

\subsection{Cell-based Assay}

Based on the SNAPtide screening results, two of the best hit compounds ChemDiv 5762-1843 and ChemDiv E843-1064 were selected for cell-based assay as lead compounds. For this assay, two lead compounds were examined for their activities in Neuro-2a cells inoculated with BoNT/A-LC. Results are shown in Figure 2 and Figure 3. ChemDiv 5762-1843 and ChemDiv E843-1064 exhibited graded inhibition at $10 \mu \mathrm{M}$. Specifically, $10 \mu \mathrm{M}$ of each compound inhibited the quantity of cleaved SNAP25 after BoNT/A-LC was transfected into the cells. These two lead compounds were not cytotoxic to Neuro2 a cells at the concentration used.

Table 1.

Hit compounds screened with high-throughput SNAPtide fluorescence assay with their corresponding DOCK energy and FPS scores

\begin{tabular}{|c|c|c|c|c|c|c|c|}
\hline Zinc ID $/$ ID & ChemDiv $^{\mathrm{b}}$ & $\mathrm{DCE}^{\mathrm{c}}$ & $\mathrm{FPS}_{\mathrm{VDW}+\mathrm{ES}}{ }^{\mathrm{d}}$ & FPS $_{\mathrm{VDW}}{ }^{\mathrm{d}}$ & $\mathrm{FPS}_{\mathrm{ES}}{ }^{\mathrm{d}}$ & $\mathrm{N}^{\mathrm{e}}$ & $\mathrm{IC}_{50}(\mu \mathrm{M})$ \\
\hline RRGC & N/A & N/A & N/A & N/A & N/A & 3 & $31 \pm 14$ \\
\hline ZINC20036308 & $5762-1843$ & -72.3 & 0.93 & 0.56 & 0.37 & 3 & $22 \pm 2$ \\
\hline ZINC21873993 & E843-1064 & -61.9 & 1.01 & 0.71 & 0.30 & 3 & $24 \pm 3$ \\
\hline ZINC00305216 & $3260-0301$ & -61.4 & 0.92 & 0.52 & 0.40 & 3 & $55 \pm 5$ \\
\hline ZINC03662371 & $\mathrm{C} 087-0323$ & -70.0 & 0.93 & 0.56 & 0.37 & 3 & $92 \pm 5$ \\
\hline ZINC20687251 & K786-5716 & -72.0 & 0.88 & 0.45 & 0.43 & 3 & $154 \pm 7$ \\
\hline ZINC04894271 & C257-0105 & -62.5 & 0.86 & 0.39 & 0.47 & 3 & $157 \pm 57$ \\
\hline ZINC12112516 & D406-0398 & -69.0 & 0.92 & 0.41 & 0.51 & 3 & $159 \pm 16$ \\
\hline
\end{tabular}

${ }^{\mathrm{a} Z I N C}$ database ID number. ${ }^{\mathrm{b}} \mathrm{ChemDiv}$ ID number. ${ }^{\mathrm{c}} \mathrm{DCE}$ scores in $\mathrm{kcal} / \mathrm{mol}$. ${ }^{\mathrm{d}} \mathrm{FPS}$ score in units of normalized Euclidian distance where 0 represents the best overlap. FPS $\mathrm{VDW}$ and $\mathrm{FPS}_{\mathrm{ES}}$ scores range from $(0,2)$ and $\mathrm{FPS}_{\mathrm{VDW}+\mathrm{ES}}$ range from $(0,4) .{ }^{\mathrm{e}}$ Number of times the assay was run. 
(A)<smiles>O=C(COc1ccccc1)Nc1ccc(F)cc1</smiles>

ChemDiv 5762-1843

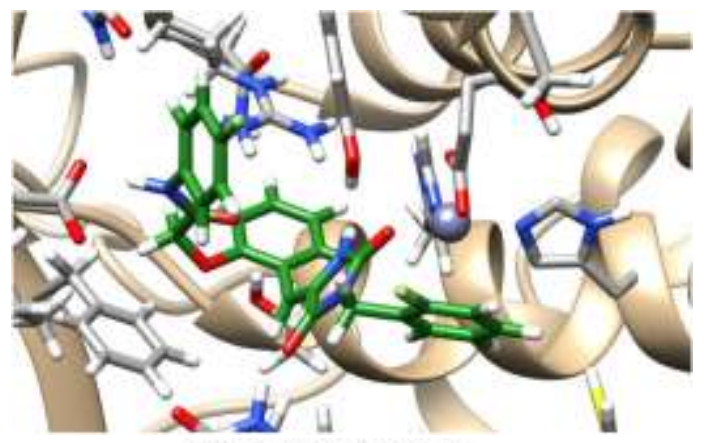

ZINC20036308 Footprint

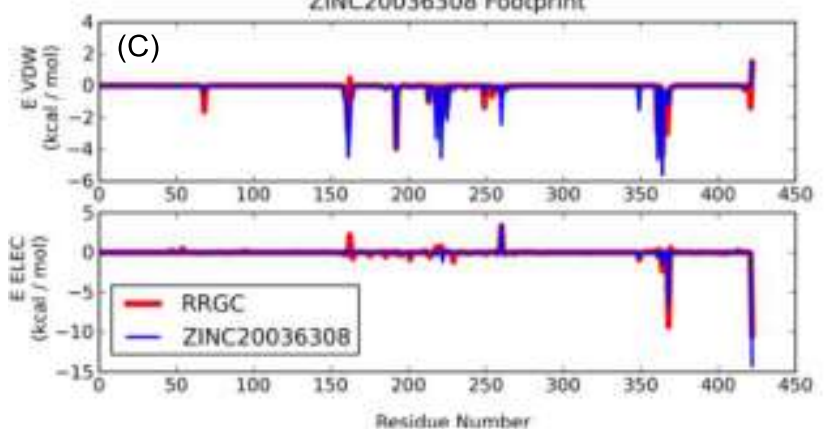

(B)<smiles>O=c1[nH]c2cc3c(cc2c(=O)n1CCc1nc(-c2ccc(C(F)(F)F)cc2)no1)OCO3</smiles>

ChemDiv E843-1064

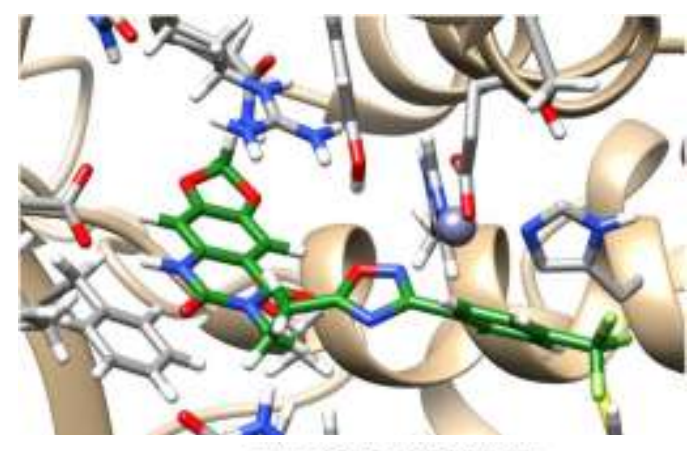

ZINC21873993 Footprint

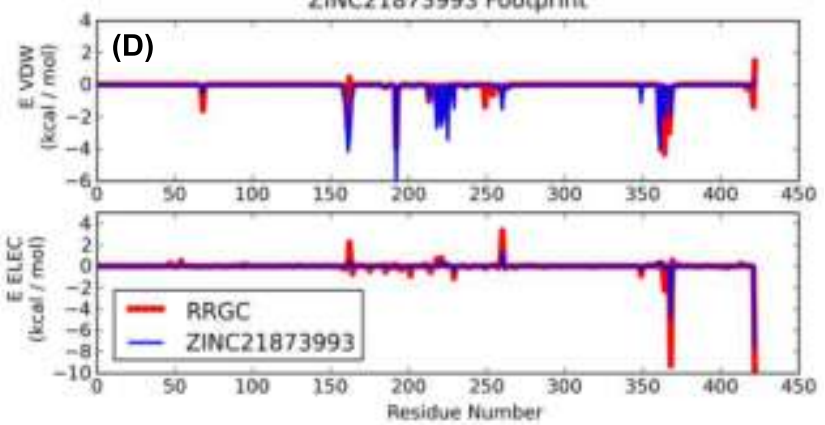

Figure 1. 2D chemical structure and 3D docked structures of hit compounds (A) ChemDiv ID 5762-1843 and (B) ChemDiv ID E843-1064. The VDW and ES footprint overlay of RRGC (red) and hit compounds (blue) (C) ChemDiv ID 5762-1843 and (D) ChemDiv ID E843-1064.

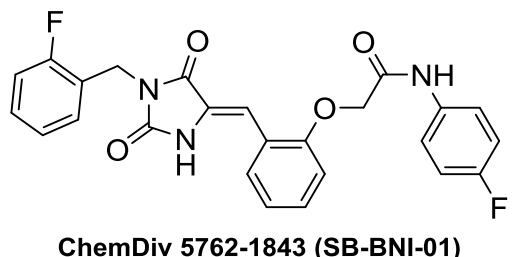

\begin{tabular}{|llllllll}
\hline 1 & 2 & 3 & 4 & 5 & 6 & \\
& & & & & & &
\end{tabular}

Figure 2. Western blot analysis of the inhibition of SNAP-25 cleavage by BoNT/A-LC in Neuro-2a cells by ChemDiv $5762-1843$ (SB-BNI-01). 1): $10 \mu \mathrm{M}$, 2) $20 \mu \mathrm{M}, 3) 50 \mu \mathrm{M}$, 4) $100 \mu \mathrm{M}$, 5) no inhibitor, 6) SNAP 25 marker.

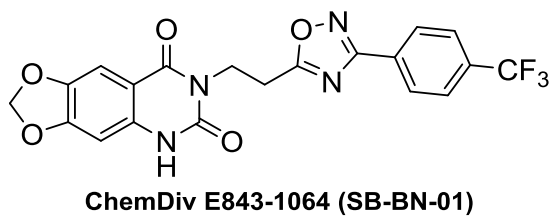

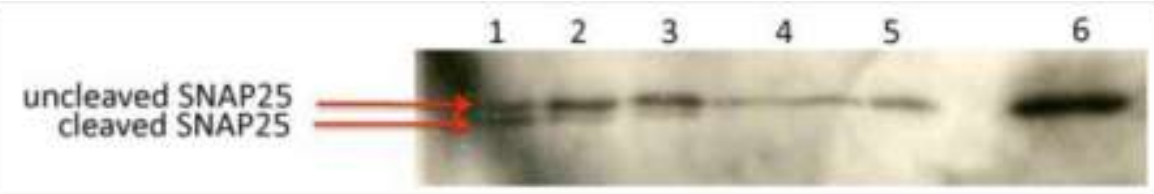

Figure 3. Western blot analysis of the inhibition of SNAP-25 cleavage by BoNT/A-LC in Neuro-2a cells by ChemDiv E843-1064 (SB-BN-01): 1) no inhibitor, 2) $10 \mu \mathrm{M}$, 3) $20 \mu \mathrm{M}$, 4) $50 \mu \mathrm{M}$, 5) $100 \mu \mathrm{M}$, 6) SNAP 25 marker. 


\subsection{Synthesis of lead compounds and analogues}

The retrosynthetic analysis of ChemDiv 5762-1843 led to two components (Scheme 1). The first component 3 was prepared starting from 4-fluoroaniline $\mathbf{1}$ in two steps. The other component 5 was prepared from imidazolidine-2,4-dione 4 with 2-fluorobenzyl bromide. Then, the Knoevenagel condensation of $\mathbf{3}$ with $\mathbf{5}$ using ethanolamine gave ChemDiv 5762-1843 (SB-BNI-01). Synthesis of ChemDiv E843-1064 was also based on the coupling of two components (Scheme 2). Quinazolinedione 9 was prepared from commercially available 6-nitropiprinol $\mathbf{6}$ in three steps. Oxadiazole $\mathbf{1 2}$ was synthesized from 4-trifluoromethyl-benzonitrile $\mathbf{1 0}$ in two steps. Coupling of $\mathbf{9}$ with 12 thus gave ChemDiv E843-1064 (SB-BN-01).

The resynthesized two hit compounds were fully characterized by ${ }^{1} \mathrm{H}$ and ${ }^{13} \mathrm{C}$ NMR and high resolution mass spectroscopy. In order to obtain a proof that the resynthesized compounds possess the same biological activities, SB-BNI-01 and SB-BN-01 were subjected to the SNAPtide assay in vitro. As Table 2 shows, SB-BNI-01 and SB-BN-01 exhibited the same $\mathrm{IC}_{50}$ values as the ChemDiv compounds within error. Thus, the structures of the ChemDiv compounds were assured.

Following the same synthetic strategy, a few analogues of the hit compounds were prepared (Figure 4) and their $\mathrm{IC}_{50}$ values determined by SNAPtide assay (Table 2). SB-BNI-03 has para-substitution at the centeral phenyl ring, but it did not drastically change the $\mathrm{IC}_{50}$ value. On the other hand, metasubstitution at the centeral phenyl ring was detrimental to the inhibition activity. SB-BN-02 was unexpectedly obtained during an attempted synthesis of one-carbon shorter SB-BN-01 analogue, which resulted in double alkylation. It is worth mentioning that SB-BN-02 exhibited higher potency than SBBN-01.
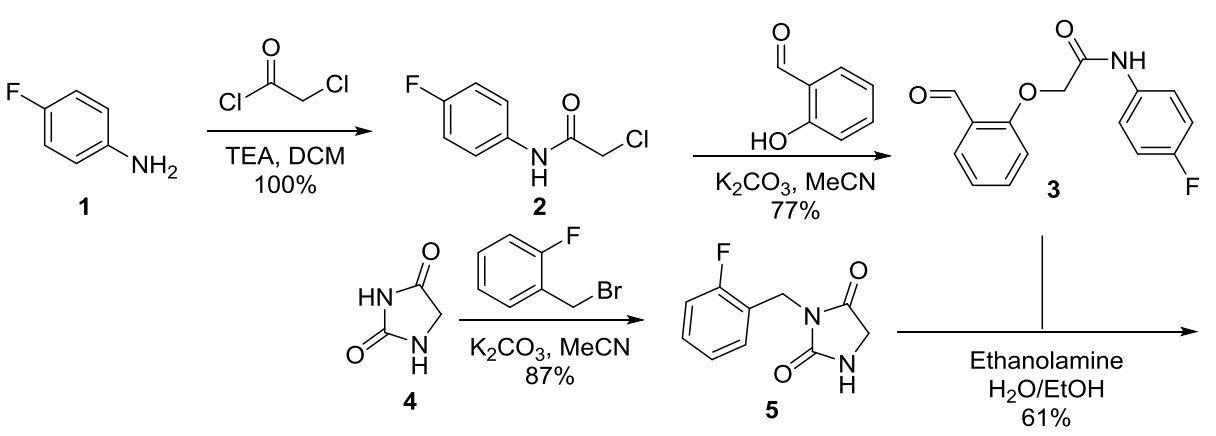

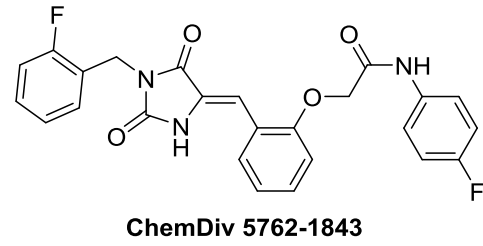

(SB-BNI-01)

Scheme 1. Synthesis of ChemDiv 5762-1843 (SB-BNI-01)

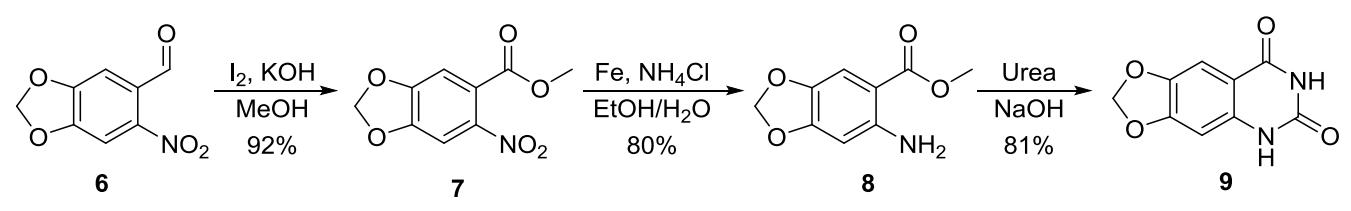<smiles>N#Cc1ccc(C(F)(F)F)cc1</smiles>

10

11

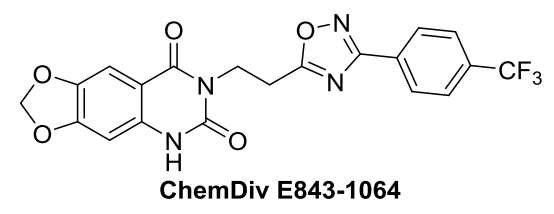

(SB-BN-01)

Scheme 2. Synthesis of ChemDiv E843-1064 (SB-BN-01)

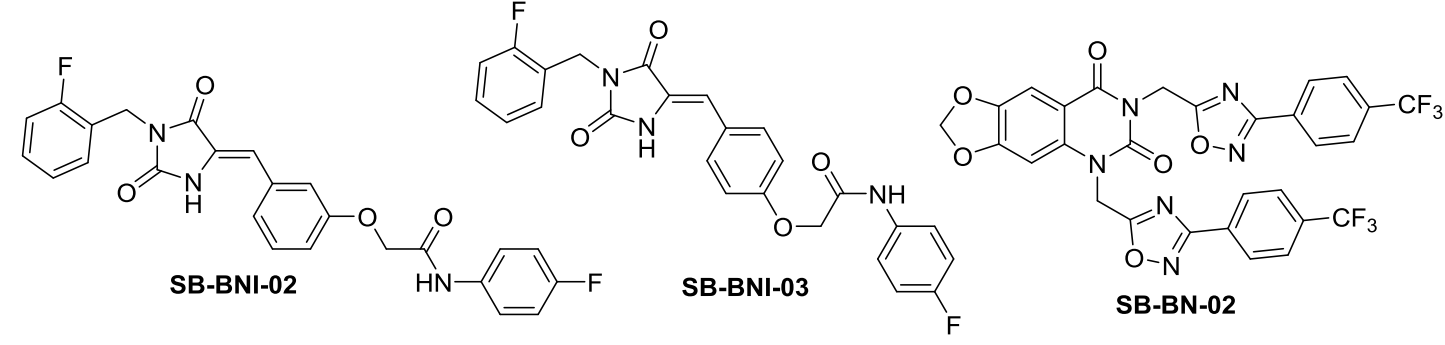

Figure 4. Analogs of lead compounds 
Table 2.

$\mathrm{IC}_{50}$ values of resynthesized lead compounds and their analogs in the SNAPtide assay

\section{Conclusion}

In summary, two promising lead compounds ChemDiv 5762-1843 and ChemDiv E843-1064 were identified from a high-throughput virtual screening implementing FPS and screened against BoNT/A-LC. Both leads showed $\mathrm{IC}_{50}$ values better than a reference inhibitor, RRGC. These lead compounds were then assayed for their activities in Neuro-2a cells against BoNT/A-LC, and found to be active at concentrations as low as $10 \mu \mathrm{M}$. Efficient synthetic routes to the lead compounds were established. The resynthesized compounds, SB-BNI-01 and SB-BN-01, were fully characterized and exhibited the same $\mathrm{IC}_{50}$ values in the SNAPtide assay as the ChemDiv compounds. Three new analogues were synthesized and assayed, and one of them, SBBN-02 exhibited better activity than the leads. Further studies on the SAR of lead compounds as well as structural biology of protein-inhibitor co-crystals are actively underway in these laboratories. A flow chart, summarizing the computer-aided drug discovery process described here, is shown in Figure 5.

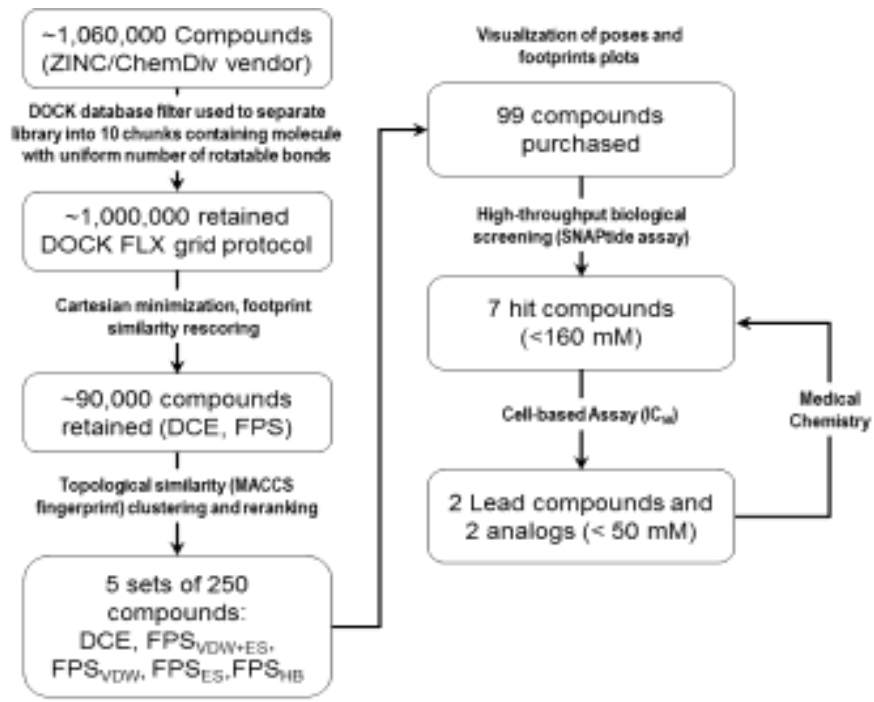

Figure 5. Flow chart for the computer-aided drug discovery of novel BoNT/A inhibitors

\section{Experimental Section}

\subsection{General Methods}

Reaction solvents were reagents grade and freshly dried, degassed and distilled before use. Anhydrous N,Ndimethylformamide (DMF) and acetonitrile were purchased from Acros Organic and used without further purification. HPLC grade acetonitrile and water were purchased from EMD. Chemicals and reagents were purchased from Alfa Aesar or Sigma-Aldrich and used without further purification unless otherwise noted. ${ }^{1} \mathrm{H}$ NMR was measured on a Bruker Avance $300 \mathrm{MHz}$, Bruker Avance $400 \mathrm{MHz}$ or Bruker Avance 500 $\mathrm{MHz}$ spectrometer at room temperature. ${ }^{13} \mathrm{C}$ NMR was measured on a Bruker Avance $400 \mathrm{MHz}$ or Bruker Avance 500 $\mathrm{MHz}$ spectrometer at room temperature. Proton chemical shifts (d) are reported in parts per million ( $\mathrm{ppm}$ ) relative to deuterated solvents as the internal standard. Coupling constants (J) are reported in Hz. Analytical HPLC in reverse phase was carried out with a Shimadzu LC-2010AHT HPLC system

\begin{tabular}{cc}
\hline Compound & $\mathrm{IC}_{50}(\mu \mathrm{M})$ \\
\hline SB-BNI-01 (ChemDiv 5762-1843) & $24 \pm 2\left(22 \pm 2^{\mathrm{a}}\right)$ \\
SB-BNI-02 & $>50$ \\
SB-BNI-03 & $26 \pm 2$ \\
SB-BN-01 (ChemDiv E843-1064) & $27 \pm 4\left(24 \pm 3^{\mathrm{a}}\right)$ \\
SB-BN-02 & $16 \pm 1$ \\
\hline
\end{tabular}

${ }^{\mathrm{a}} \mathrm{IC}_{50}$ value for the ChemDiv compound

using a Waters Nova-Pak C18 (60̊̊, $4 \mu \mathrm{m}, 3.9 \mathrm{~mm}$ X 150 $\mathrm{mm}$ ) analytical column with water/acetonitrile as mobile phase. Melting points were measured on a Thomas-Hoover Capillary melting point apparatus and are uncorrected. TLC analyses were performed using Merck DC Alufolien 60F254 aluminum pre-coated silica gel plates. Flash column chromatography was carried out using Silicyle SiliaFlashP60® silica gel (particle size 40_63 $\mu \mathrm{m}$ ). High-resolution mass spectrometric analyses were carried out by ICB\&DD at Stony Brook University. Unless otherwise noted all reactions were carried out under nitrogen atmosphere in oven-dried glassware using standard Schlenck techniques.

\subsection{Virtual Screening using FPS}

A high-throughput virtual screening of over one million molecules from the ChemDiv subset of the ZINC database (http://zinc.docking.org) was conducted on New York Blue, an 18 rack IBM Blue Gene/L massively parallel supercomputer located at Brookhaven National Laboratory using DOCK version 6.5. ${ }^{12-14}$ Prior to docking, the most updated ChemDiv database was download and presorted by rotatable bonds and split into 10 subsets of $\sim 100,000$ molecules using the DOCK database filter. Subsequently, energy grids for BoNT/A-LC (PDB: 3C88) were generated using the grid program. Then, each molecule was flexibly docked to the BONT/A-LC grid (DOCK FLX protocol) and the single lowest-energy pose was retained.

Following high-throughput virtual screening, the footprintbased rescoring methodology reported by Balius et. al. ${ }^{15}$ was implemented to enrich the library of docked molecules. First, the co-crystallized reference ligand RRGC was minimized on the BoNT/A-LC Cartesian coordinated within the binding pocket. This was implemented using both a hydrogen optimization followed by a weak restrained minimization (restraint of $10 \mathrm{kcal} / \mathrm{mol}$ ). Following reference minimization, each molecule of the docked library was subsequently minimized in Cartesian space using the restrained minimization protocol. Last, electrostatic, van der Waals, and hydrogen bond footprint similarity scores were computed using normalized Euclidian distance for each molecule docked versus the reference using DOCK 6.5.

Subsets 1 through 5 and subsets 6 through 10 each contained $\sim 500,000$ molecules were rank-ordered by the DOCK Cartesian energy score (DCE). The top 45,000 of each combined subsets (total $\sim 90,000$ molecules) were than clustered using MACCS fingerprints as implemented in the $\mathrm{MOE}^{16}$ program with the Tanimoto coefficient of 0.75 . The resulting cluster heads were further rank-ordered by: 1) standard DOCK score (DCE $\mathrm{VDW}+\mathrm{ES})$, 2) van der Waals footprint similarity score $\left(\mathrm{FPS}_{\mathrm{VDW}}\right)$, 3) electrostatic footprint similarity score $\left(\mathrm{FPS}_{\mathrm{ES}}\right)$, 4) H-bond footprint similarity score $\left.\left(\mathrm{FPS}_{\mathrm{HB}}\right), 5\right)$ sum of van der Waals and electrostatic footprint similarity score $\left(\mathrm{FPS}_{\mathrm{VDW}+\mathrm{ES}}\right)$. The top 250 molecules rank- 
ordered by each criteria were then plotted and examined by visual inspection and consistency to the reference footprint. Based on this approach, 99 compounds were selected and purchased for biological testing against BoN-LC.

\subsection{Biology}

\subsubsection{SNAPtide Assay}

Materials: BoNT/A-LC truncated 1-425 was provided by Dr. Swaminathan at Brookhaven National Laboratory, Upton, NY. RRGC was provided by Dr. Swaminathan at Brookhaven National Laboratory, Upton, NY. Corning 96-well black microplates (Corning, NY). SNPAtide (List, Biological Laboratories, Inc., Campbell, CA). Full length BoNT/A (Metabiologics, Inc., Madison, WI). Primary antibody, anti SNAP-25 mouse monoclonal IgG1 $(200 \mu \mathrm{g} / \mathrm{mL}$; Santa Cruz Biotechnology, Dallas, TX). Secondary antibody, donkey antimouse HRP conjugated $(200 \mu \mathrm{g} / 0.5 \mathrm{~mL}$; Santa Cruz Biotechnology).

The activity of BoNT/A-LC was measured in 96 well plates by the use of a Synergy 2 plate reader at $485 \mathrm{~nm}$ excitation and $528 \mathrm{~nm}$ emission. Stock solutions of inhibitors were prepared at $10 \mathrm{mM}$ with DMSO. Assays contained $40 \mathrm{mM}$ Hepes $(\mathrm{pH}$ 7.4) buffer, $100 \mathrm{nM}$ of enzyme, $0.15 \mathrm{mM} \mathrm{ZnCl}{ }_{2}, 1.25 \mathrm{mM}$ DTT, and varying concentrations of inhibitor in a final volume of $100 \mu \mathrm{L}$. Assay were initiated by the addition of $5 \mu \mathrm{M}$ SNAPtide. Initial rates were measured from the linear region of each assay, 100 to $300 \mathrm{~s}$. IC50 values were determined by the equation $\mathrm{IC}_{50}=\left([\mathrm{I}] \mathrm{V} / \mathrm{V}_{0}\right) /\left(1-\mathrm{V} / \mathrm{V}_{0}\right)$, where $[\mathrm{I}]$ is the concentration of inhibitor $\mathrm{V}_{0}$ is the initial rate in the absence of inhibitor, and $\mathrm{V}$ is the initial rate in the presence of inhibitor.

\subsubsection{Cell-based Assay}

Inhibitors were assessed for their ability to protect SNAP25 from cleavage by BoNT/A as described ${ }^{17,18}$ with slight modifications. Briefly, Neuro-2a cells (ATCC CCL-131) were grown on $75 \mathrm{~cm}^{2}$ tissue culture flasks in Eagle's Minimum Essential Medium with salt containing $2 \mathrm{mM}$ L-glutamine, 1.5 $\mathrm{g} / \mathrm{L}$ sodium bicarbonate, $0.1 \mathrm{mM}$ nonessential amino acids, $1 \%$ penicillin-streptomycin, $1.0 \mathrm{mM}$ sodium pyruvate and $10 \%$ fetal bovine serum at $37{ }^{\circ} \mathrm{C}$ in an atmosphere of $5 \% \mathrm{CO}_{2}$ and $95 \%$ air. Once cells were $70-80 \%$ confluent they were seeded in 24-well tissue cultures plates at a density of $\sim 5 \times 10^{5} / \mathrm{mL}$. After 48 hours, the medium was replaced with serum-free medium and cells were grown for an additional 24 hours. Cells were then incubated with $1 \mu \mathrm{g}$ of full length BoNT/A and various concentrations of inhibitors for 48 hours. Cells were harvested and proteins were separated by SDS-PAGE using a $12.5 \%$ gel. Proteins were transferred onto a nitrocellulose membrane that was blocked with milk followed by treatment with 1:1000 dilution of SNAP-25 mouse monoclonal antibody and subsequent treatment with 1:2000 dilution of donkey antimouse HRP. The membrane was treated with West Dura Chemiluminescent Substrate (Pierce) and exposed to x-ray film.

\subsection{Chemistry}

\subsubsection{3-(2-Fluorobenzyl)imidazolidine-2,4- dione (5)}

To the solution of hydantoin $4(1.00 \mathrm{~g}, 1.00 \mathrm{mmol})$ and 2fluorobenzyl bromide $(1.794 \mathrm{~g}, 0.95 \mathrm{mmol})$ in $\mathrm{MeCN}(40 \mathrm{~mL})$ was added $\mathrm{K}_{2} \mathrm{CO}_{3}(2.762 \mathrm{~g}, 2.00 \mathrm{mmol})$ and the reaction was heated to $80{ }^{\circ} \mathrm{C}$ for overnight. The reaction was diluted with DCM (40 mL), filtered through Celite and concentrated. The crude was purified by recrystallization from DCM/hexanes to give 5 as white solid $\left(1.724\right.$ g, 87\%): m.p.: $133-134{ }^{\circ} \mathrm{C} ;{ }^{1} \mathrm{H}$ NMR (300 MHz, Chloroform-d): $\delta 4.03$ (s, 2H), 4.78 (s, 2H), 5.89 (bs, 1H), 7.04-7.14 (m, 2H), 7.27-7.38 (m, 2H); ${ }^{13} \mathrm{C}$ NMR (100 MHz, Chloroform-d) $\delta 35.92(J=4.6 \mathrm{~Hz}), 46.51,115.62$ $(J=21.2 \mathrm{~Hz}), 122.59(J=14.6 \mathrm{~Hz}), 124.23(J=3.7 \mathrm{~Hz})$, $129.74(J=8.1 \mathrm{~Hz}), 130.17(J=3.6 \mathrm{~Hz}), 157.96,160.59(J=$ $246.7 \mathrm{~Hz}$ ), 170.81; HRMS (ESI-TOF) $\mathrm{m} / \mathrm{e}$ calcd for $[\mathrm{M}+\mathrm{H}]^{+}$ $\mathrm{C}_{10} \mathrm{H}_{10} \mathrm{FN}_{2} \mathrm{O}_{2}$ : 209.0726, found 209.0729 ( $\triangle 1.4 \mathrm{ppm}$ ).

\subsection{2. $N$-(4-Fluorophenyl)-2-chloroacetamide (2)}

To the solution of 4-fluoroaniline $(0.600 \mathrm{~g}, 5.40 \mathrm{mmol})$ and TEA $(0.600 \mathrm{~g}, 5.94 \mathrm{mmol})$ in $\operatorname{DCM}(15 \mathrm{~mL})$ was added dropwise chloroacetyl chloride $(0.671 \mathrm{~g}, 5.94 \mathrm{mmol})$, and the reaction was stirred at room temperature for overnight. The reaction was washed with water $(20 \mathrm{ml})$, brine $(20 \mathrm{~mL})$, dried over $\mathrm{MgSO}_{4}$ and concentrated to give $\mathbf{2}$ as off-white solid (1.01 g, crude quantitative): m.p.: $131-132{ }^{\circ} \mathrm{C} ;{ }^{1} \mathrm{H}$ NMR $(300 \mathrm{MHz}$, Chloroform-d): $\delta 4.21$ (s, 2H), $7.08(\mathrm{t}, J=8.60 \mathrm{~Hz}, 2 \mathrm{H}), 7.53$ $(\mathrm{dd}, J=8.60 * 4.71 \mathrm{~Hz}, 2 \mathrm{H}), 8.23(\mathrm{bs}, 1 \mathrm{H})$. The analytical data was consistent with literature data. ${ }^{19}$

\subsubsection{General procedure for the synthesis of 2 - (formylphenoxy)acetamide (3)}

To the solution of hydroxyaldehyde $(2.0 \mathrm{mmol})$ and $2(2.0$ $\mathrm{mmol})$ in $\mathrm{MeCN}(20 \mathrm{~mL})$ was added $\mathrm{K}_{2} \mathrm{CO}_{3}(3.0 \mathrm{mmol})$ and the reaction was heated to $80{ }^{\circ} \mathrm{C}$ for overnight. The reaction was cooled to room temperature, diluted with DCM $(50 \mathrm{~mL})$, filtered through Celite and concentrated. The crude was purified by column chromatography (silica gel, EtOAc/Hexanes $=5 \% \rightarrow 30 \%$ ) to afford 3a-c.

\subsection{4. $N$-(4-Fluorophenyl)-2-(2-formylphenoxy)- acetamide (3a)}

White solid, 77\%: m.p.: 123-125 ${ }^{\circ} \mathrm{C} ;{ }^{1} \mathrm{H}$ NMR (300 MHz, Chloroform-d): $\delta 4.71(\mathrm{~s}, 2 \mathrm{H}), 6.99-7.11(\mathrm{~m}, 3 \mathrm{H}), 7.27(\mathrm{t}, \quad J=$ $7.62 \mathrm{~Hz}, 1 \mathrm{H}), 7.65(\mathrm{~m}, 1 \mathrm{H}), 7.79-7.88(\mathrm{~m}, 3 \mathrm{H}), 10.05$ (bs, $1 \mathrm{H})$, $10.11(\mathrm{~s}, 1 \mathrm{H}) ;{ }^{13} \mathrm{C}$ NMR (100 MHz, Chloroform-d) $\delta 67.72$, $113.52,115.66(J=22.4 \mathrm{~Hz}), 121.31(J=7.8 \mathrm{~Hz}), 122.28$, $125.04,133.96(J=2.8 \mathrm{~Hz}), 136.32,136.38,157.08,159.47(J$ $=241.8 \mathrm{~Hz}), 165.50,191.32$; HRMS (ESI-TOF) $\mathrm{m} / \mathrm{e}$ calcd for $[\mathrm{M}+\mathrm{Na}]^{+} \mathrm{C}_{15} \mathrm{H}_{12} \mathrm{FNNaO}_{3}: 296.0699$, found 296.0722 ( $\triangle 7.7$ ppm).

\subsection{5. $N$-(4-Fluorophenyl)-2-(3-formylphenoxy)- acetamide (3b)}

White solid, 70\%: m.p.: 101-102 ${ }^{\circ} \mathrm{C} ;{ }^{1} \mathrm{H}$ NMR $(300 \mathrm{MHz}$, Chloroform-d): $\delta 4.68(\mathrm{~s}, 2 \mathrm{H}), 7.06(\mathrm{t}, J=8.49 \mathrm{~Hz}, 2 \mathrm{H}), 7.28$ $(\mathrm{d}, J=8.01 \mathrm{~Hz}, 1 \mathrm{H}), 7.50-7.60(\mathrm{~m}, 5 \mathrm{H}), 8.29$ (bs, 1H), 10.05 (s, 1H); ${ }^{13} \mathrm{C}$ NMR (100 MHz, Chloroform-d) $\delta 67.61,113.87$, $115.86(J=22.6 \mathrm{~Hz}), 121.28,122.04(J=7.8 \mathrm{~Hz}), 124.97$, $130.70,132.69(J=2.9 \mathrm{~Hz}), 138.14,167.49,159.80(J=243.1$ $\mathrm{Hz}), 165.43,191.46$; HRMS (ESI-TOF) $\mathrm{m} / \mathrm{e}$ calcd for $[\mathrm{M}]^{+}$ $\mathrm{C}_{15} \mathrm{H}_{13} \mathrm{FNO}_{3}$ : 274.0879, found 464.1422 ( $\Delta 5.4 \mathrm{ppm}$ ).

\subsubsection{N-(4-Fluorophenyl)-2-(4-formylphenoxy)- acetamide $(3 \mathrm{c})$}

White solid, 72\%: m.p.: 118-120 ${ }^{\circ} \mathrm{C} ;{ }^{1} \mathrm{H}$ NMR (300 MHz, Chloroform-d): $\delta 4.71(\mathrm{~s}, 2 \mathrm{H}), 7.04-7.15(\mathrm{~m}, 4 \mathrm{H}), 7.55-7.59$ (m, 2H), $7.92(\mathrm{~d}, J=8.55 \mathrm{~Hz}, 2 \mathrm{H}), 8.22(\mathrm{bs}, 1 \mathrm{H}), 9.95(\mathrm{~s}, 1 \mathrm{H})$; ${ }^{13} \mathrm{C}$ NMR (100 MHz, Chloroform-d) $\delta 67.43,115.13,115.88(J$ 
$=22.5 \mathrm{~Hz}), 122.15(\mathrm{~J}=7.9 \mathrm{~Hz}), 131.39,132.22,132.58(\mathrm{~J}=$ $2.9 \mathrm{~Hz}), 159.86(J=243.3 \mathrm{~Hz}), 161.49,165.16,190.56$; HRMS (ESI-TOF) $m / e$ calcd for $[\mathrm{M}]^{+} \mathrm{C}_{15} \mathrm{H}_{13} \mathrm{FNO}_{3}$ : 274.0879, found 274.0927 ( $\Delta 17.5 \mathrm{ppm})$.

\subsubsection{General Procedure for the synthesis of SB-BNI compounds}

To the suspension of $5(1.0 \mathrm{mmol})$ and $3(1.0 \mathrm{mmol})$ in water $(5 \mathrm{~mL})$ was added $\mathrm{EtOH}(3 \mathrm{~mL})$ and ethanolamine $(3.0$ $\mathrm{mmol})$, and the reaction was heated to $105{ }^{\circ} \mathrm{C}$ for overnight. The reaction mixture was cooled to room temperature and diluted with water $(20 \mathrm{~mL})$. The product was collected by vacuum filtration and dried over phosphorus pentoxide under vacuum. The product was purified by recrystallization in $\mathrm{MeOH}$ to afford BNI compound.

4.4.8. (Z)-2-(2-((1-(2-Fluorobenzyl) - 2,5-dioxoimidazolidin-4-ylidene)methyl) phenoxy) - N-(4fluorophenyl)acetamide (ChemDiv5762-1843, SB-BNI-01)

White solid 61\%: m.p.: 222-224 ${ }^{\circ} \mathrm{C}$; ${ }^{1} \mathrm{H}$ NMR (400 MHz, DMSO-d $\left._{6}\right): \delta 4.74(\mathrm{~s}, 2 \mathrm{H}), 4.88(\mathrm{~s}, 2 \mathrm{H}), 6.85(\mathrm{~s}, 1 \mathrm{H}), 7.02(\mathrm{~m}$, 2H), 7.14-7.40 (m, 7H), $7.62(\mathrm{~m}, 3 \mathrm{H}), 10.34(\mathrm{~s}, 1 \mathrm{H}), 10.77$ (s, $1 \mathrm{H}) ;{ }^{13} \mathrm{C}$ NMR (100 MHz, DMSO-d $\left.{ }_{6}\right) \delta 35.81,35.85,67.46$, $105.83,112.41,115.78,115.97,116.00,121.82,121.90$, $122.22,123.53,123.67,125.03,125.07,127.28,130.05$, $130.09,130.17,130.82,130.88,135.08,135.11,154.75$, $155.96,157.57,159.10,159.96,161.54,164.23,167.17$; HRMS (ESI-TOF) $m / e$ calcd for $[\mathrm{M}+\mathrm{H}]^{+} \mathrm{C}_{25} \mathrm{H}_{20} \mathrm{~F}_{2} \mathrm{~N}_{3} \mathrm{O}_{4}$ : 464.1416, found 464.1422 ( $\Delta 1.3 \mathrm{ppm})$.

4.3.9. (Z)-2-(3-((1-(2-Fluorobenzyl)-2,5-dioxoimidazolidin4-ylidene)methyl)phenoxy)- $N$-(4-fluorophenyl)acetamide (SB-BNI-02)

White solid, 64\%: m.p.: 212-213 ${ }^{\circ} \mathrm{C}$; ${ }^{1} \mathrm{H}$ NMR (400 MHz, DMSO-d $\left.{ }_{6}\right): \delta 4.73(\mathrm{~s}, 2 \mathrm{H}), 4.78(\mathrm{~s}, 2 \mathrm{H}), 6.56(\mathrm{~s}, 1 \mathrm{H}), 7.05(\mathrm{~m}$, $1 \mathrm{H}), 7.14-7.38(\mathrm{~m}, 9 \mathrm{H}), 7.67(\mathrm{~m}, 2 \mathrm{H}), 10.11(\mathrm{~s}, 1 \mathrm{H}), 10.96(\mathrm{~s}$, $1 \mathrm{H}) ;{ }^{13} \mathrm{C}$ NMR (100 MHz, DMSO-d $\left.{ }_{6}\right) \delta 35.89,35.93,67.64$, $110.25,115.60,115.67,115.76,115.90,115.97,116.16$, $122.11,122.19,123.27,123.45,123.59,125.04,125.07$, $130.05,130.09,130.19,130.37,134.54,135.14,135.16$, $155.28,157.57,158.46,159.10,159.96,161.54,164.30$, 166.92; HRMS (ESI-TOF) $m / e$ calcd for $[\mathrm{M}+\mathrm{H}]^{+}$ $\mathrm{C}_{25} \mathrm{H}_{20} \mathrm{~F}_{2} \mathrm{~N}_{3} \mathrm{O}_{4}$ : 464.1416, found 464.1436 ( $\triangle 4.3 \mathrm{ppm}$ ).

\subsubsection{0. (Z)-2-(4-((1-(2-Fluorobenzyl)-2,5-dioxoimidazolidin- 4-ylidene)methyl)phenoxy)- $N$-(4-fluorophenyl)acetamide (SB-BNI-03)}

Yellow solid 62\%: m.p.: >240 ${ }^{\circ} \mathrm{C} ;{ }^{1} \mathrm{H}$ NMR $(400 \mathrm{MHz}$, DMSO-d $\left.{ }_{6}\right): \delta 4.73(\mathrm{~s}, 2 \mathrm{H}), 4.76(\mathrm{~s}, 2 \mathrm{H}), 6.56(\mathrm{~s}, 1 \mathrm{H}), 7.05(\mathrm{~d}, J$ $=8.76 \mathrm{~Hz}, 2 \mathrm{H}), 7.15-7.38(\mathrm{~m}, 6 \mathrm{H}), 7.65(\mathrm{~m}, 4 \mathrm{H}), 10.18(\mathrm{~s}$, $1 \mathrm{H}), 10.78(\mathrm{~s}, 1 \mathrm{H}) ;{ }^{13} \mathrm{C}$ NMR $\left(100 \mathrm{MHz}, \mathrm{DMSO}-\mathrm{d}_{6}\right) \delta 35.79$, 35.84, 67.51, 110.66, 115.55, 115.70, 115.76, 115.92, 115.96, $122.01,122.09,123.54,123.69,125.03,125.06,125.29$, $126.35,129.98,130.02,130.07,130.15,131.75,135.15$, $135.17,155.18,157.56,158.63,159.08,159.95,161.52$, 164.37, 166.72; HRMS (ESI-TOF) $\mathrm{m} / e$ calcd for $[\mathrm{M}+\mathrm{H}]^{+}$ $\mathrm{C}_{25} \mathrm{H}_{20} \mathrm{~F}_{2} \mathrm{~N}_{3} \mathrm{O}_{4}: 464.1416$, found 464.1454 ( $\Delta 8.2 \mathrm{ppm}$ ).

\subsubsection{Methyl-6-nitro-1,3-benzodioxole-5-carboxylate (7)}

To a solution of 6-nitropiprinol $6(1.01 \mathrm{~g}, 5.12 \mathrm{mmol})$ in absolute methanol $(7 \mathrm{~mL})$ cooled at $0{ }^{\circ} \mathrm{C}$ were successively added methanolic solution ( $10 \mathrm{~mL}$ each) of iodine $(3.9 \mathrm{~g}, 15.4$ mmol) and $\mathrm{KOH}(855 \mathrm{mg}, 15.4 \mathrm{mmol})$ at $0{ }^{\circ} \mathrm{C}$. After stirring for $1.5 \mathrm{~h}$, small amount of saturated solution of sodium bisulfite was added until the disappearance of the brown color. The solvent was evaporated under the reduced pressure and to the residue was added water. The desired product was obtained by filteration as yellow solid (1.06 g, $92 \%$ yield); ${ }^{1} \mathrm{H}$ NMR (300 MHz, Chloroform-d): $\delta 3.89$ (s, 3H), 6.17 (s, 2H), 7.04 (s, $1 \mathrm{H}), 7.39(\mathrm{~s}, 1 \mathrm{H})$. The analytical data was consistent with literature data. ${ }^{20}$

\subsubsection{Methyl-6-amino-1,3-benzodioxole-5-carboxylate (8)}

A mixture of ethyl-6-nitro-1,3-benzodioxole-5-carboxylate (1.01 g, $4.44 \mathrm{mmol})$, powder metallic iron (1.24 g, $22.2 \mathrm{mmol})$ and ammonium chloride (142 mg, $2.66 \mathrm{mmol})$ in ethanol/water $(2: 1,75 \mathrm{~mL})$ was refluxed for $1 \mathrm{~h}$. After the completion of the reaction, the reaction mixture was filtered over celite and filterate was concentrated under reduced pressure to give $\mathbf{8}$ as dark yellow solid (0.700 g, $80 \%$ yield); ${ }^{1} \mathrm{H}$ NMR $(300 \mathrm{MHz}$, Chloroform-d): $\delta 3.82$ (s, 3H), $5.72(\mathrm{bs}, 2 \mathrm{NH}), 5.89$ (s, 2H), $6.16(\mathrm{~s}, 1 \mathrm{H}), 7.25(\mathrm{~s}, 1 \mathrm{H})$. The analytical data was consistent with literature data. ${ }^{20}$

\subsubsection{6,7-Methylenedioxy-quinazoline-2,4(1H,3H)-dione} (9)

A mixture of methyl-6-amino-1,3-benzodioxole-5carboxylate $(0.437 \mathrm{~g}, 2.24 \mathrm{mmol})$ and urea $(1.34 \mathrm{~g}, 22.4 \mathrm{mmol})$ was heated to $160{ }^{\circ} \mathrm{C}$ in a sealed tube for $15 \mathrm{~h}$. The reaction mixture was cooled down to room temperature and 10 eq. of 2 $\mathrm{M}$ solution of sodium hydroxide was added to the reaction mixture and stirred at room temperature was 24 hours. The reaction mixture was acidified with $1 \mathrm{M}$ solution of hydrochloric acid and the precipitate was filtered to give $\mathbf{9}$ as white solid ( $0.374 \mathrm{~g}, 81 \%$ yield); ${ }^{1} \mathrm{H}$ NMR (300 MHz, DMSO$\left.\mathrm{d}_{6}\right): \delta 6.10(\mathrm{~s}, 2 \mathrm{H}), 6.63(\mathrm{~s}, 1 \mathrm{H}), 7.21(\mathrm{~s}, 1 \mathrm{H}), 11.01(\mathrm{~s}, 1 \mathrm{H})$, $11.17(\mathrm{~s}, 1 \mathrm{H})$. The analytical data was consistent with literature data. $^{21}$

\subsubsection{4-Trifluoromethyl- $N$-hydroxybenzamidine (11)}

A mixture of 4-trifluoromethylbenzonitrile $\mathbf{1 0}(0.350 \mathrm{~g}$, $2.04 \mathrm{mmol})$, hydroxylamine hydrochloride $(0.213 \mathrm{~g}, 3.07$ $\mathrm{mmol})$ and triethylamine $(0.44 \mathrm{~mL}, 3.24 \mathrm{mmol})$ in ethanol $(4$ $\mathrm{mL}$ ) was refluxed for $3 \mathrm{~h}$. After the completion of the reaction, the solvent was evaporated the crude residue was dissolved in dichloromethane and washed with water and brine once. The organic layer was dried over magnesium sulfate, filtered and evaporated to give $\mathbf{1 1}$ as white solid (0.406 g, 99\%); ${ }^{1} \mathrm{H}$ NMR (300 MHz, Chloroform-d): $\delta 4.88$ (bs, 2NH), 7.23 (s, 1H), 7.67 $(\mathrm{d}, J=8.1 \mathrm{~Hz}, 2 \mathrm{H}), 7.76(\mathrm{~d}, J=8.1 \mathrm{~Hz}, 2 \mathrm{H})$. The analytical data was consistent with literature data. ${ }^{22}$

\subsubsection{5-Chloroethyl-3-(4-trifluoromethylphenyl)- $[1,2,4]$ oxa-diazole (12)}

A solution of chloropropionyl chloride $(0.031 \mathrm{~g}, 0.25$ $\mathrm{mmol})$ in benzene $(0.35 \mathrm{ml})$ was added drop wise to of 4trifluoromethyl- $N$-hydroxybenzamidine $(0.1 \mathrm{~g}, 0.49 \mathrm{mmol})$ in benzene $(3 \mathrm{ml})$. The reaction mixture was refluxed at $80{ }^{\circ} \mathrm{C}$ for 12 hours. The reaction as monitored by TLC. The reaction mixture was evaporated under vacuum to obtain the crude product, which was purified by flash column chromatography using silica gel and ethyl acetate/hexanes (gradient 5-10\% ethyl acetate/hexanes) as eluent to give $\mathbf{1 2}$ as colorless oil (52 mg, $79 \%$ yield); ${ }^{1} \mathrm{H}$ NMR (500 MHz, Chloroform-d): $\delta 3.46$ $(\mathrm{t}, J=6.9 \mathrm{~Hz}, 2 \mathrm{H}), 4.00(\mathrm{t}, J=6.9 \mathrm{~Hz}, 2 \mathrm{H}), 7.75(\mathrm{~d}, J=8.1$ 
$\mathrm{Hz}, 2 \mathrm{H}), 8.21(\mathrm{~d}, J=8.1 \mathrm{~Hz}, 2 \mathrm{H}) ;{ }^{13} \mathrm{C}$ NMR $(125 \mathrm{MHz}$, Chloroform-d) $\delta 30.54,39.57,123.95(\mathrm{q}, J=271.0 \mathrm{~Hz})$, $126.11(\mathrm{q}, J=3.6 \mathrm{~Hz}), 128.06,130.19,133.24$ (q, $J=32.5$ $\mathrm{Hz}$ ), 167.74, 177.03; HRMS (ESI-TOF) $\mathrm{m} / \mathrm{e}$ calcd for $[\mathrm{M}+\mathrm{H}]^{+}$ $\mathrm{C}_{11} \mathrm{H}_{9} \mathrm{ClF}_{3} \mathrm{~N}_{2} \mathrm{O}: 277.0350$, found 277.0348 ( $\left.\Delta 0.7 \mathrm{ppm}\right)$.

\subsubsection{E843-1064 (SB-BN-01)}

A mixture of 6,7-methylenedioxy-quinazoline-2,4(1H,3H)dione $\quad(50 \mathrm{mg}, \quad 0.23 \mathrm{mmol})$, 5-chloroethyl-3-(4trifluoromethylphenyl)-[1,2,4]0xadiazole (72 mg, $0.26 \mathrm{mmol})$ and potassium carbonate $(36 \mathrm{mg}, 0.26 \mathrm{mmol})$ in dimethyl sulfoxide $(2 \mathrm{~mL})$ was heated to $60{ }^{\circ} \mathrm{C}$ for $6 \mathrm{~h}$. The crude reaction mixture was diluted with ethyl acetate and washed with water several times. The organic layer was dried over magnesium sulfate, filtered and evaporated to give the crude mixture which was purified by column chromatography (silica gel, EtOAc/Hexanes $=30 \% \rightarrow 60 \%$ ) to afford SB-BN-01 as white solid (37 mg, $35 \%$ yield), m.p.: $224-226{ }^{\circ} \mathrm{C} ;{ }^{1} \mathrm{H}$ NMR $\left(300 \mathrm{MHz}\right.$, Acetone- $\left.\mathrm{d}_{6}\right): \delta 3.42(\mathrm{t}, J=6.9 \mathrm{~Hz}, 2 \mathrm{H}), 4.48(\mathrm{t}, J=$ $6.9 \mathrm{~Hz}, 2 \mathrm{H}), 6.15(\mathrm{~s}, 2 \mathrm{H}), 6.77(\mathrm{~s}, 1 \mathrm{H}), 7.31(\mathrm{~s}, 1 \mathrm{H}), 7.91(\mathrm{~d}, J$ $=8.1 \mathrm{~Hz}, 2 \mathrm{H}), 8.24(\mathrm{~d}, J=8.1 \mathrm{~Hz}, 2 \mathrm{H}), 10.25(\mathrm{bs}, 1 \mathrm{H}) ;{ }^{13} \mathrm{C}$ NMR $\left(100 \mathrm{MHz}\right.$, Acetone-d $\left.{ }_{6}\right) \delta$ 24.73, 37.32, 95.14, $102.59,104.76,107.73,125.96,126.00,127.81,130.82$, 136.86, 144.42, 150.02, 153.94,161.40,167.05, 178.42; HRMS (ESI-TOF) m/e calcd for $[\mathrm{M}+\mathrm{H}]^{+} \mathrm{C}_{20} \mathrm{H}_{14} \mathrm{~F}_{3} \mathrm{~N}_{4} \mathrm{O}_{5}$ : 447.0916, found $447.0938(\Delta 4.9 \mathrm{ppm})$.

\subsubsection{SB-BN-02}

A mixture of 6,7-methylenedioxy-quinazoline-2,4(1H,3H)dione $\quad(50 \mathrm{mg}, \quad 0.24 \mathrm{mmol})$, 5-chloromethyl-3-(4trifluoromethyl-phenyl)[1,2,4]oxadiazole ${ }^{23}$ (70 mg, $\left.0.27 \mathrm{mmol}\right)$ and potassium carbonate $(37 \mathrm{mg}, 0.27 \mathrm{mmol})$ in dimethyl sulfoxide $(3 \mathrm{~mL})$ was heated to $60{ }^{\circ} \mathrm{C}$ for $6 \mathrm{~h}$. The crude reaction mixture was diluted with ethyl acetate and washed with water several times. The organic layer was dried over magnesium sulfate, filtered and evaporated to give the crude mixture which was purified by column chromatography (silica gel, EtOAc/Hexanes $=1 \% \rightarrow 30 \%$ ) to afford SB-BN-02 as white solid (24 mg, $15 \%$ yield), m.p.: $196-198{ }^{\circ} \mathrm{C}$; ${ }^{1} \mathrm{H}$ NMR $\left(300 \mathrm{MHz}\right.$, Acetone- $\left.\mathrm{d}_{6}\right): \delta 5.65(\mathrm{~s}, 2 \mathrm{H}), 5.90(\mathrm{~s}, 2 \mathrm{H}), 6.23(\mathrm{~s}$, $2 \mathrm{H}), 7.30(\mathrm{~s}, 1 \mathrm{H}), 7.55(\mathrm{~s}, 1 \mathrm{H}), 7.88(\mathrm{~m}, 4 \mathrm{H}), 8.21(\mathrm{~d}, J=8.0$ $\mathrm{Hz}, 4 \mathrm{H}) ;{ }^{13} \mathrm{C}$ NMR (100 MHz, Acetone- $\left.\mathrm{d}_{6}\right) \delta 37.44,40.44$, 95.68, 103.26, 105.72, 108.85, 122.66, 125.36, 125.95, 125.99, $126.03,126.07,126.11,126.15,127.91,127.95,130.13$, $130.32,132.19,132.32,132.52,132.64,137.50,145.06$, $150.46,155.05,160.01,167.30,167.37,175.94,176.45$; HRMS (ESI-TOF) m/e calcd for $[\mathrm{M}+\mathrm{H}]^{+} \mathrm{C}_{29} \mathrm{H}_{17} \mathrm{~F}_{6} \mathrm{~N}_{6} \mathrm{O}_{6}$ : 659.1108 , found $659.1108(\Delta 0 \mathrm{ppm})$.

\section{Acknowledgment}

This research was supported by a grant from the Defense Threat Reduction Agency (DTRA), Department of Defense (TCBM.THRTOX.01.10.BNL.017 to S.S.).

\section{Supplementary Data}

Supplementary data associated with this article can be found, in

the online version, at http://dx.doi.org/Xxxxxxxxxxxxxxxxxxxxx

\section{References and Notes}

1. Arnon, S. S.; Schechter, R.; Inglesby, T. V.; et al. JAMA 2001, 285, 1059.

2. Gill, D. M. Microbiol Rev 1982, 46, 86.

3. Burnett, J. C.; Henchal, E. A.; Schmaljohn, A. L.; Bavari, S. Nat Rev Drug Discov 2005, 4, 281.

4. Franz, D. R.; Jahrling, P. B.; Friedlander, A. M.; et al. JAMA 1997, 278, 399.

5. Hackett, R.; Kam, P. C. A. Med Chem 2007, 3, 333.

6. Masuyer, G.; Chaddock, J. A.; Foster, K. A.; Acharya, K. R. Ann Rev Pharmacol Tox 2014, 54, 27.

7. Tighe, A. P.; Schiavo, G. Toxicon 2013, 67, 87.

8. Schiavo, G.; Rossetto, O.; Montecucco, C. Semin Cell Biol 1994, 5, 221.

9. Swaminathan, S.; Eswaramoorthy, S. Nat Struct Mol Biol 2000, 7, 693.

10. In Medical Toxicology; Ellenhorn M.J., B. D. G., Ed.; Elsevier: New York, 1988.

11. Kumaran, D.; Rawat, R.; Ludivico, M. L.; Ahmed, S. A.; Swaminathan, S. J Biol Chem 2008, 283, 18883.

12. Peters, A.; Lundberg, M.; Lang, P.; Sosa, C.; REDP-4410, 2008.

13. Lang, P. T.; Brozell, S. R.; Mukherjee, S.; Pettersen, E. F.; Meng, E. C.; Thomas, V.; Rizzo, R. C.; Case, D. A.; James, T. L.; Kuntz, I. D. Rna 2009, 15, 1219.

14. Mukherjee, S.; Balius, T. E.; Rizzo, R. C. Journal of chemical information and modeling 2010, 50, 1986.

15. Balius, T. E.; Mukherjee, S.; Rizzo, R. C. J Comput Chem 2011, 32, 2273

16. Molecular Operating Environment (MOE), Chemical Computing Group Inc.: 1010 Sherbooke St. West, Suite \#910, Montreal, QC, Canada, H3A 2R7 2011.

17. Boldt, G. E.; Eubanks, L. M.; Janda, K. D. Chem Commun 2006, 3063

18. Eubanks, L. M.; Hixon, M. S.; Jin, W.; Hong, S.; Clancy, C. M.; Tepp, W. H.; Baldwin, M. R.; Malizio, C. J.; Goodnough, M. C.; Barbieri, J. T.; Johnson, E. A.; Boger, D. L.; Dickerson, T. J.; Janda, K. D. Proc Natl Acad Sci USA 2007, 104, 2602.

19. Ma, L.; Xie, C.; Ma, Y.; Liu, J.; Xiang, M.; Ye, X.; Zheng, H.; Chen, Z.; Xu, Q.; Chen, T.; Chen, J.; Yang, J.; Qiu, N.; Wang, G.; Liang, X.; Peng, A.; Yang, S.; Wei, Y.; Chen, L. J Med Chem 2011, 54, 2060.

20. Maia, R. C.; Silva, L. L.; Mazzeu, E. F.; Fumian, M. M.; de Rezende, C. M.; Doriguetto, A. C.; Corrêa, R. S.; Miranda, A. L. P.; Barreiro, E. J.; Fraga, C. A. M. Bioorg Med Chem 2009, 17, 6517.

21. Barbosa, M. L. d. C.; Lima, L. M.; Tesch, R.; Sant'Anna, C. M. R.; Totzke, F.; Kubbutat, M. H. G.; Schächtele, C.; Laufer, S. A.; Barreiro, E. J. Eur J Med Chem 2014, 71, 1.

22. Lin, C.-C.; Hsieh, T.-H.; Liao, P.-Y.; Liao, Z.-Y.; Chang, C.W.; Shih, Y.-C.; Yeh, W.-H.; Chien, T.-C. Org Lett 2014, 16, 892.

23. Ozcan, S.; Kazi, A.; Marsilio, F.; Fang, B.; Guida, W. C.; Koomen, J.; Lawrence, H. R.; Sebti, S. M. J Med Chem 2013, $56,3783$. 


\section{Graphical Abstract}

To create your abstract, type over the instructions in the template box below.

Fonts or abstract dimensions should not be changed or altered.

\section{Computer-Aided Identification, Synthesis, and Biological Evaluation of Novel Inhibitors for Botulinum Neurotoxin Serotype A}

Yu-Han Gary Teng, William T. Berger, Natasha M. Nesbitt, Kunal Kumar, Trent E. Balius, Robert C. Rizzo, Peter J. Tonge, Iwao Ojima* and Subramanyam Swaminathan

Institute of Chemical Biology and Drug Discovery, Department of Chemistry, and Department of Applied Mathematics and Statistics, Stony Brook University; Biological, Environmental \& Climate Sciences Department, Brookhaven National Laboratory, New York, United States

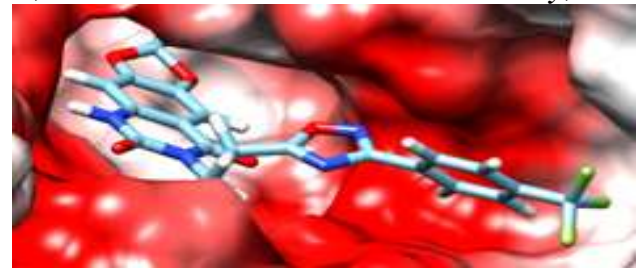

HTP in-silico screening of ZINC database \

SNAPtide assay in vitro

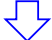

Inhibition of SNAP 25 cleavage in Neuro-2a cells

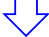

Two promising lead compounds and their analogues 